\title{
Seasonal abundance and vertical distribution of Protozoa (flagellates, ciliates) and bacteria in Lake Kinneret, Israel
}

\author{
Ora Hadas*, Tom Berman \\ Israel Oceanographic \& Limnological Research, The Yigal Allon Kinneret Limnological Laboratory, PO Box 345 ,
} Tiberias 14102, Israel

\begin{abstract}
The seasonal and vertical abundances of ciliates and flagellates are described over a 2 yr period in Lake Kinneret, Israel, a warm meso-eutrophic monomictic lake. Ciliate numbers ranged from 3 to 47 cells $\mathrm{ml}^{-1}$. At the thermocline and oxycline region, the highest ciliate numbers were observed in autumn, with Coleps hirtus as the dominant species. Maximum heterotrophic nanoflagellate abundance ( 1300 cells $\mathrm{ml}^{-1}$ ) was found in the epilimnion in winter-spring, minimum numbers (66 cells $\mathrm{ml}^{-1}$ ) occurred in autumn. Bacteria ranged from $10^{5}$ to $3.10^{7}$ cells $\mathrm{ml}^{-1}$ with highest numbers at the decline of the Peridinium gatunense bloom and the lowest during winter. Protozoa, especially ciliates, appeared to be important food sources for metazooplankton. Top-down control is an important factor determining the structure of the microbial loop in Lake Kinneret.
\end{abstract}

KEY WORDS: HNAN Ciliates Bacteria - Lake Kinneret

\section{INTRODUCTION}

The abundance and distribution of microorganisms in aquatic ecosystems result from a complex of environmental factors and trophic interactions among a multitude of biotic components. In lakes, as in the marine habitat, important fluxes of carbon nutrients and energy are mediated by the microbial food web (Pomeroy 1974, Azam et al. 1983), consisting of bacteria, picophytoplankton and protozoa (Nagata 1988, Bloem \& Bar-Gilissen 1989, Sanders et al. 1989, 1992, Weisse \& Muller 1990, Berninger et al. 1991). In some circumstances, the predation of metazoan zooplankton on components of the microbial food web may transfer carbon, other nutrients and energy into the classical food chain, i.e. to fish via metazoan zooplankton (Dolan \& Gallegos 1991). Thus, several studies have suggested that ciliates can be an important food source

•E-mail: orah@ocean.org.il for zooplankton in both marine and aquatic environments (Beaver \& Crisman 1989, Pace et al. 1990, Stoecker \& Capuzzo 1990).

The abundance of each component within the microbial loop, i.e. bacteria, picophytoplankton, flagellates and ciliates, is controlled by some combination of bottom-up (nutrient supply) and top-down (grazing) regulation. Heterotrophic nanoflagellates (HNAN) are frequently the dominant consumers of bacteria and picoplankton, determining the abundance of the latter in many aquatic ecosystems. Ciliates, mixotrophic flagellates, rotifers and cladocerans can also be significant grazers of bacteria and picophytoplankton (Bird \& Kalff 1984, Sherr et al. 1986, Nagata 1988, Pace et al. 1990, Weisse \& Muller 1990. Berninger et al. 1991, Sanders et al. 1992). In freshwaters, daphnid zooplankters with their broad feeding capabilities have also been reported to be important consumers of bacteria, protozoa and small algae (Porter et al. 1979, Pace et al. 1990, Sanders \& Porter 1990). 
Although many aspects of the ecosystem of Lake Kinneret, Israel, have been extensively studied and much information is available about the phytoplankton and zooplankton of this warm, mesotrophic-eutrophic lake, as yet relatively little has been published about the protozoan components of the plankton. An early paper of Pollingher \& Kimor (1967) listed some of the tintinnids and Madoni (1990) reported on the major ciliate species in this lake. Sherr et al. (1982) and Hadas et al. (1990) described experimental studies with lake flagellates which clearly indicated the importance of these organisms as agents of nutrient recycling and breakdown of organic detritus. Other work (Sherr et al. 1991) showed the potential of ciliates as grazers of picophytoplankton in this lake. In this paper we give an overview of the seasonal abundance and vertical distribution of heterotrophic flagellates, ciliates and bacteria in Lake Kinneret from November 1988 to September 1992.

\section{MATERIALS AND METHODS}

Sampling was carried out twice a month in 1989 and monthly in 1990 and 1991 at Stn A, the deepest (42 m) location at the center of the lake, representative for the pelagic waters, at different depths $(1,5,10,20,30$ and $40 \mathrm{~m}$ ). At each depth, water was taken with a RodheAberg sampler and transferred to the laboratory in dark glass bottles (1.51). Flagellate, ciliate and bacterial numbers in these samples were determined from November 1988 to July 1991. Subsamples $(20 \mathrm{ml})$ for protozoan counts were preserved with $10 \mu \mathrm{l}$ of alkaline-Lugol's, $0.5 \mathrm{ml}$ of $40 \%$ formalin and $30 \mu \mathrm{l}$ of thiosulfate (Sherr et al. 1991). For determination of bacterial abundance, $20 \mathrm{ml}$ samples were fixed with $1.4 \mathrm{ml}$ of $0.2 \mu \mathrm{m}$ filtered $5 \%$ formaldehyde and stored at $4^{\circ} \mathrm{C}$ until counting. Aliquots $(5 \mathrm{ml})$ of the preserved subsamples of protozoa and bacteria were filtered onto 0.8 and $0.2 \mu \mathrm{m}$ Nuclepore membrane filters respectively and stained with DAPI (Porter \& Feig 1980). Enumeration of heterotrophic nanoflagellates and bacteria was made at $1000 \times$ and ciliates at $400 \times$ using a Zeiss epifluorescence microscope (Axioscope) with a $\mathrm{HBO}$ $50 \mathrm{~W}$ bulb and with optical filter settings: excitation 365; beam splitter FT 395; barrier filter: P420. At least 60 fields per filter were counted for HNAN and ciliates. Biovolumes of these organisms were estimated based on their geometrical shapes: ciliates as oblate spheroids, and heterotrophic flagellates as spheres or oblate spheroids. Conversion to carbon biomass was made using a factor of 0.14 for ciliates (Putt \& Stoecker 1989) and $0.22 \mathrm{pg} \mathrm{C} \mathrm{\mu m}^{-3}$ for HNAN (Borsheim \& Bratbak 1987 ). For bacteria a minimum of 400 to 500 cells was always counted. The bacterial dimensions were cali- brated with an optical micrometer. Dissolved oxygen was determined by the Winkler method according to Standard Methods (APHA 1989)

\section{RESULTS}

\section{Environmental conditions during the study period (1989 to 1991)}

Seasonal stratification and oxic conditions

During January through April the lake was homothermic with temperatures of about $15^{\circ} \mathrm{C}$ within the whole water column. Strong thermal stratification which was established in the lake in May and June lasted until the middle or end of December. From the end of April until August, the temperature of the epilimnetic layer increased from 15 to $28^{\circ} \mathrm{C}$ and then decreased till the end of December. The depth of the thermocline varied from 14 to $22 \mathrm{~m}$ with most rapid deepening starting in October. Hypolimnetic water temperatures ranged from 14 to $16^{\circ} \mathrm{C}$ with little seasonal variation.

During the homothermic period, dissolved oxygen (DO) was distributed evenly in the water column at Stn $A_{1}$, reaching values of 11 to $14 \mathrm{mg} \mathrm{O}_{2} l^{-1}$. In April, a thermocline began to develop in the upper water layer at 3 to $5 \mathrm{~m}$ whereas an oxycline at $40 \mathrm{~m}$ formed as the result of $\mathrm{H}_{2} \mathrm{~S}$ release from the sediments, which lowered hypolimnetic oxygen concentrations to $1.5 \mathrm{mg} \mathrm{l}^{-1}$. Thus, the thermocline and oxycline during April were located at distinctly different depths. By early summer, the hypolimnion became completely depleted of oxygen and remained anoxic until mid- to late December. In summer and autumn, DO in the epilimnion ranged from 8.2 to $8.8 \mathrm{mg} \mathrm{O}_{2} \mathrm{I}^{-1}$. The oxycline coincided with the thermocline, with DO concentrations in the metalimnion varying from 0.2 to $5.9 \mathrm{mg} \mathrm{O}_{2} \mathrm{l}^{-1}$.

\section{Phytoplankton}

The annual bloom of Peridinium gatunense from February-March through early June coincided with the greater part of the homothermic period in the lake. The dinoflagellates contributed more than $90 \%$ of the total phytoplankton biomass during winter and spring with maxima in April or May; 184, 243 and $251 \mathrm{~g}$ wet weight $\mathrm{m}^{-2}$, in 1989, 1990 and 1991 respectively (data: U. Pollingher; Fig. 1). During summer and autumn when the phytoplankton community consisted mostly of chlorophyta, the total biomass ranged from 7.0 to $50 \mathrm{~g}$ wet weight $\mathrm{m}^{-2}$. The decline of the dinoflagellate bloom in late May or early June supplied the water col- 


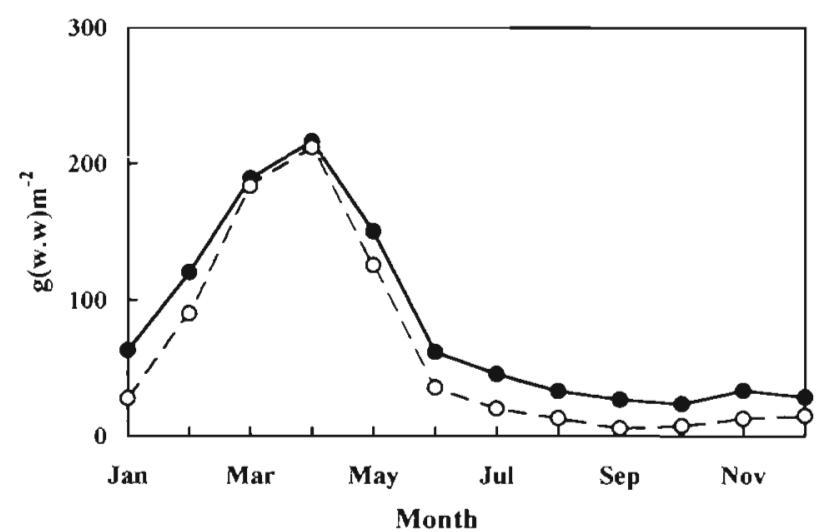

Fig. 1. Seasonal variations in phytoplankton biomass. (1) Total phytoplankton biomass; (0) Peridinium biomass. Average 1989 to 1991

umn and the sediment with organic matter, stimulating bacterial heterotrophic activity (Berman et al. 1979, Cavari \& Hadas 1979).

\section{Annual and seasonal abundance of ciliates}

The abundance of ciliates expressed in terms of cell numbers and carbon biomass, averaged for the entire water column at Stn A from November 1988 to August 1991, is shown in Fig. 2. The greatest numbers of ciliates occurred in autumn (October 1989) and in spring. Carbon biomass and cell numbers were usually, but not always, well correlated (see Table 1). Ciliate numbers and carbon biomass ranged from 3 to $47{\text { cells } \mathrm{ml}^{-1}}^{-1}$ and 1.4 to $17 \mathrm{mg} \mathrm{C} \mathrm{m}^{-3}$, respectively.

The vertical distribution of ciliate numbers and biomass during different seasons in 1989 is presented in Fig. 3. Relatively low numbers of ciliates were seen in February. In April, a peak of 64 ciliates $\mathrm{ml}^{-1}$ with a biovolume of $433 \mathrm{~mm}^{3} \mathrm{~m}^{-3}$ (Carbon biomass, $61 \mathrm{mg} \mathrm{C} \mathrm{m}^{-3}$ ) was recorded at $40 \mathrm{~m}$ which consisted mostly of anaerobic or facultative ciliates. After the onset of thermal stratification, and with the demise of the Peridinium gatunense bloom (May-June), high densities of ciliates were found in the thermocline or/and hypolimnion. With the deepening of the thermocline and oxycline below the photic zone after October there was an increase in ciliate numbers and biovolume $(99$ cells $\mathrm{ml}^{-1}$ and $275 \mathrm{~mm}^{3} \mathrm{~m}^{-3}$ respectively).

\section{Ciliate populations in Lake Kinneret}

The major ciliate classes observed in Lake Kinneret were the Oligohymenophorea and Spirotrichea (Madoni 1990). In Fig. 4, we show the seasonal pattern of relative abundance of the major ciliate orders in the lake from November 1988 through November 1989.

Within the Oligohymenophorea, the order Scuticociliatida (Cyclidium sp., Dexiotricha sp., Pleuronema sp.) was abundant in autumn; 59 ind. $\mathrm{ml}^{-1}$ were counted in November 1988. Cyclidium was mainly found in the epilimnion, while Dexiotricha was domi-

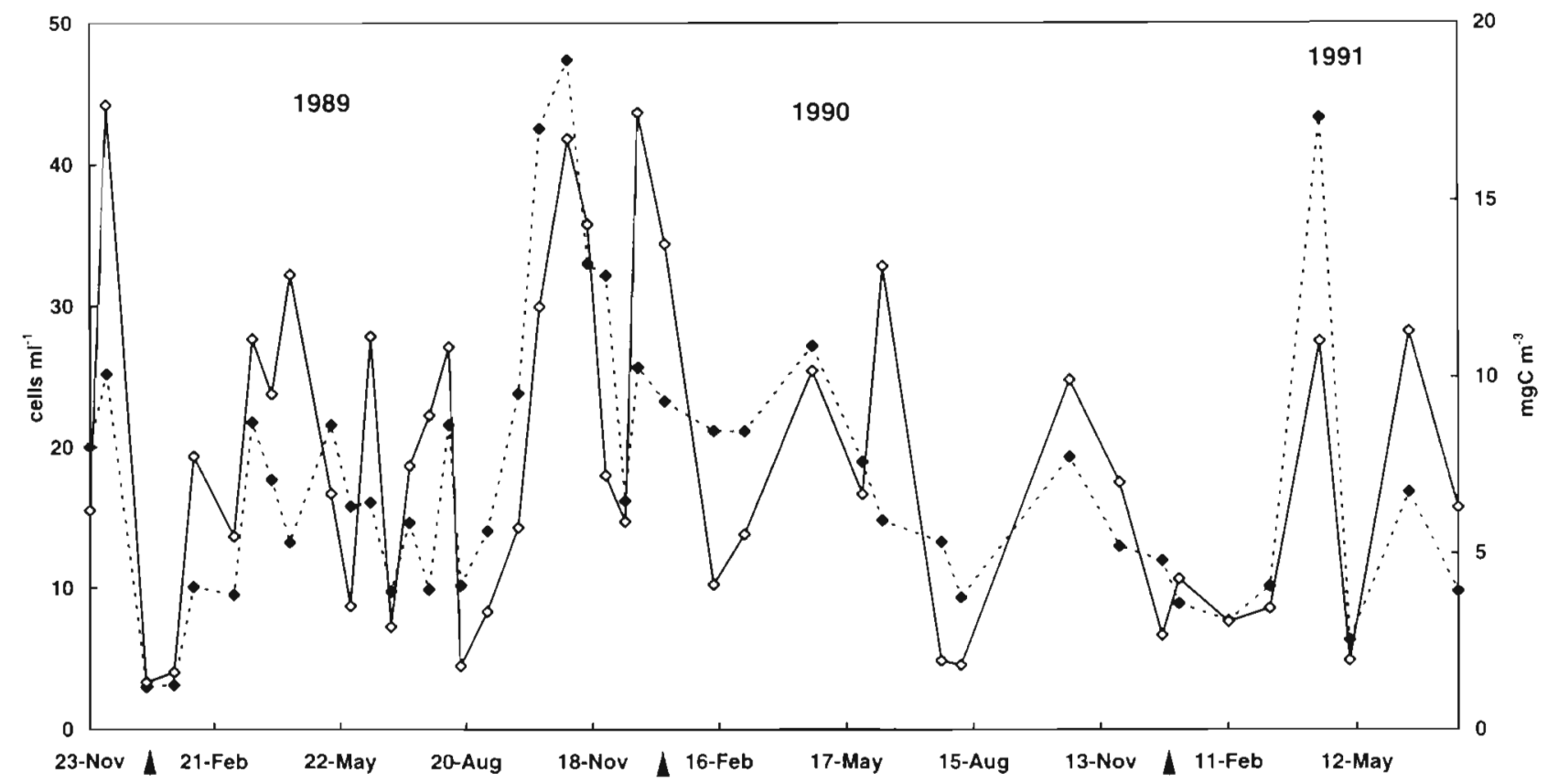

Fig. 2. Seasonal abundance of Lake Kinneret ciliates: $(\bullet)$ average $(0$ to $10 \mathrm{~m})$ cell numbers $\mathrm{ml}^{-1},(\diamond)$ carbon biomass 

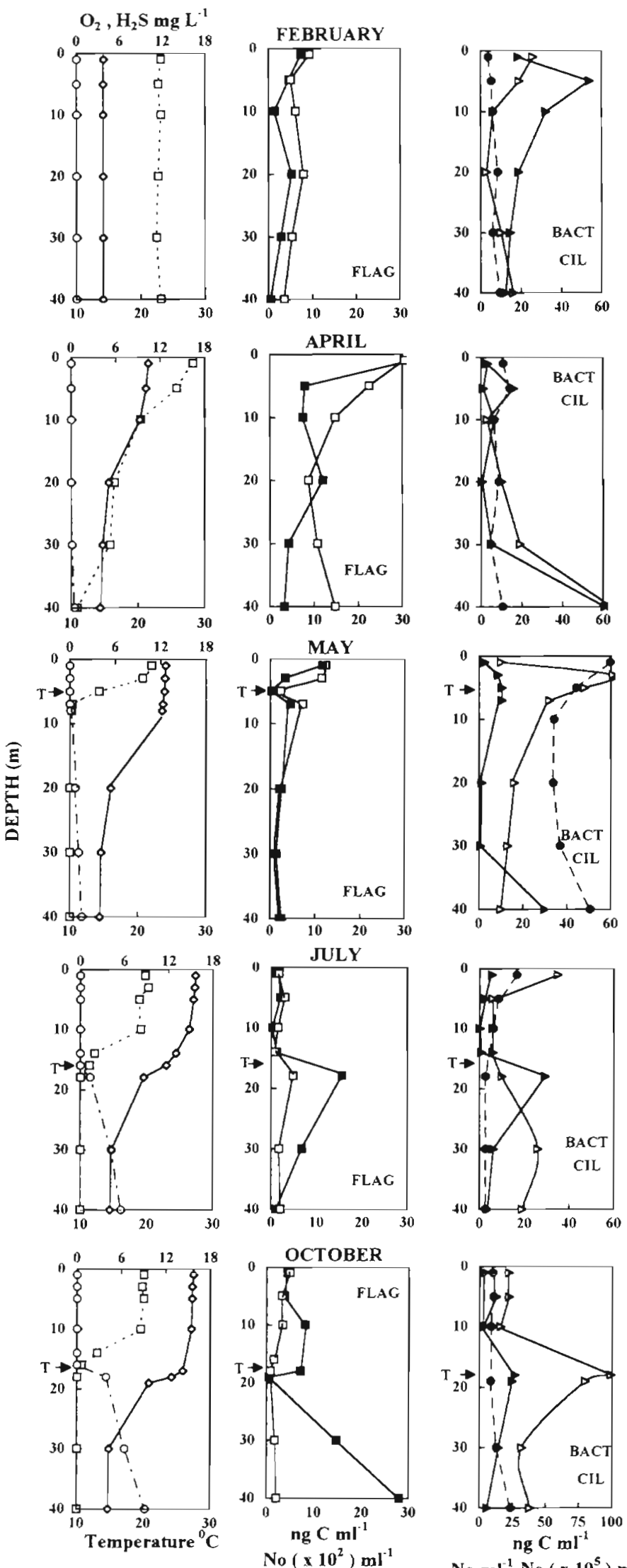

nant in the anaerobic hypolimnion. With the decline of the dinoflagellate bloom in May 1989, an additional peak of Scuticociliatida was observed within the thermocline region in which there were high concentrations of organic matter and bacteria. Colpoda steinii (16 ind. $\mathrm{ml}^{-1}$ in June 1989), which has a high tolerance to $\mathrm{NH}_{4}$ and to low concentrations of dissolved oxygen (Bick 1972), was particularly prominent in this water layer.

The order Sessilida (primarily represented by Vorticella mayerii) reached its highest densities (13 ind. $\mathrm{ml}^{-1}$ ) in February, during the period of lake homothermy.

Within the class of Spirotrichea, the orders Choreotrichida and Oligotrichida were abundant throughout the year. However, the genera tintinnidium were observed only in February and early March, when the entire water column was strongly mixed and dissolved oxygen concentrations were high. Microscopic observation indicated that these organisms were mainly feeding on diatoms, flagellates and bacteria.

The order Haptorida (represented by Didinium sp., Askensia sp., Mesodinium sp.) was found during autumn, winter and spring but only occasionally during summer (May to August). These organisms are carnivorous, feeding on other ciliates (Bick 1972).

The most abundant ciliate species in Lake Kinneret during our study was Coleps hirtus (class Prostomatea, order Prorodontida) which was generally found dispersed throughout the water column. Maximum numbers of this organism were observed in October 1989 (59 ind $\mathrm{ml}^{-1}$ ) and high abundances were located within the thermocline and hypolimnion during the stratified period. Individuals of $C$. hirtus contained zoochlorellae and microscopic observation indicated that they were feeding on nano- and pico-sized algae, flagellates and small ciliates.

During the period of lake stratification (from May through December), we noted relatively large ciliate populations in the anaerobic hypolimnetic water which contained high con-

Fig. 3. Vertical distrabution of: (left panels) temperature $(\diamond)$, oxygen $(\square)$ and $\mathrm{H}_{2} \mathrm{~S}(O)$; (centre panels) flagellate numbers $(\square)$ and biomass ( $\square$ ): (right panels) ciliate numbers $(\triangleright)$, ciliate biomass $(\downarrow)$ and bacterial numbers $\times 10^{5} \mathrm{~mJ}^{-1}(\bullet)$, in Lake Kinneret in 1989. $\mathrm{T} \rightarrow$ : depth of thermocline 
centrations of $\mathrm{H}_{2} \mathrm{~S}$ (ranging from 1 to $12 \mathrm{mg} \mathrm{S} \mathrm{l}^{-1}$ ). The major ciliate genera observed in this region were Metopus, Caenomorpha, Epalxella, Plagiopyla, Brachonella and Saprodinium, all which are known to tolerate anaerobic conditions and the presence of $\mathrm{H}_{2} \mathrm{~S}$ (Fenchel et al. 1990). These ciliates were feeding on sulfur cycle bacteria (e.g. Thiovulum sp., Beggiatoa sp., and other bacteria as well as organic detritus (Hadas unpubl. data).

\section{Heterotrophic nanoflagellates}

The seasonal abundance of flagellates from November 1988 through August 1991 and their vertical distribution in 1989 are shown in Figs. 3 \& 5. Small (2 to $5 \mu \mathrm{m}$ ) monads were the most abundant HNAN forms. The numbers of HNAN showed definite seasonal peaks during the late winter-spring months of 1989 and 1990, concomitantly with the bloom of Peridinium gatunense. Maximum flagellate numbers (averaged for the whole water column) were recorded in March and April 1989 (1350 cells ml-1), while minimum numbers (66 cells $\mathrm{ml}^{-1}$ ) were found in November 1989 (Fig. 3). Flagellates increased from January (900 cells $\mathrm{ml}^{-1}$ with a biovolume of $32 \mathrm{~mm}^{3} \mathrm{~m}^{-3}$ at $5 \mathrm{~m}$ depth) to a maximum 3000 cells $\mathrm{ml}^{-1}$ and a biovolume of $146 \mathrm{~mm}^{3}$ $\mathrm{m}^{-3}$ in April coincident with the peak of $P$. gatunense biomass (Fig. 3). Although HNAN were distributed throughout the water column including the anaerobic hypolimnion during the entire year, the maximum

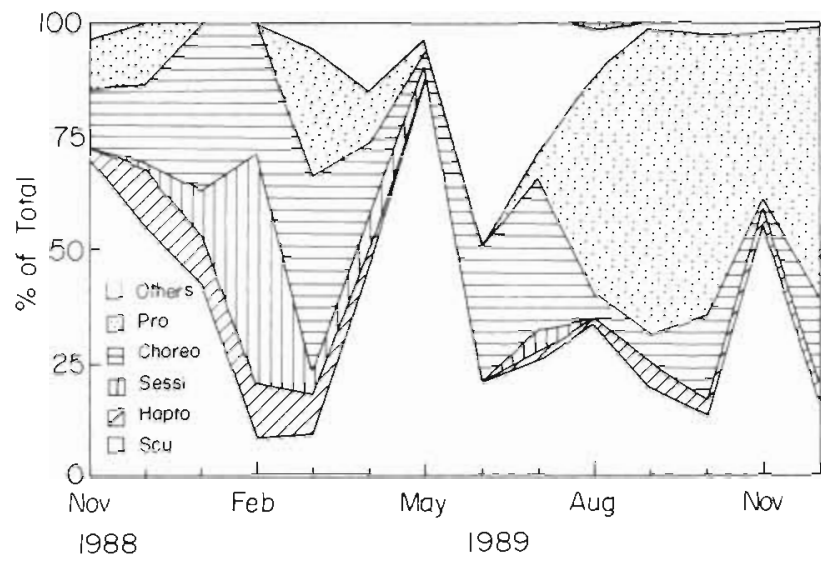

Fig. 4. Abundance of major ciliate orders in Lake Kinneret from November 1988 to November 1989. Scu: Scuticociliatida; Choreo: Choreotrichida; Hapto: Haptorida; Pro: Prorodontida; Sessi: Sessilida; Others: Saprodinium, Caenomorpha, Colpoda

numbers of these organisms were found in the upper water layers in winter and spring.

The carbon biomass of HNAN did not show the same clear seasonal pattern as HNAN cell numbers although both parameters exhibited apparent 2 to 3 mo minimum-maximum cycles similar to those found for the ciliates (Figs. $3 \& 5$ ).

Sometimes small numbers of large flagellates were responsible for relatively high HNAN biomass carbon in the vertical profiles. For example, in October, most of the flagellate biomass in the hypolimnion was due to the presence of a few large organisms. In contrast, the

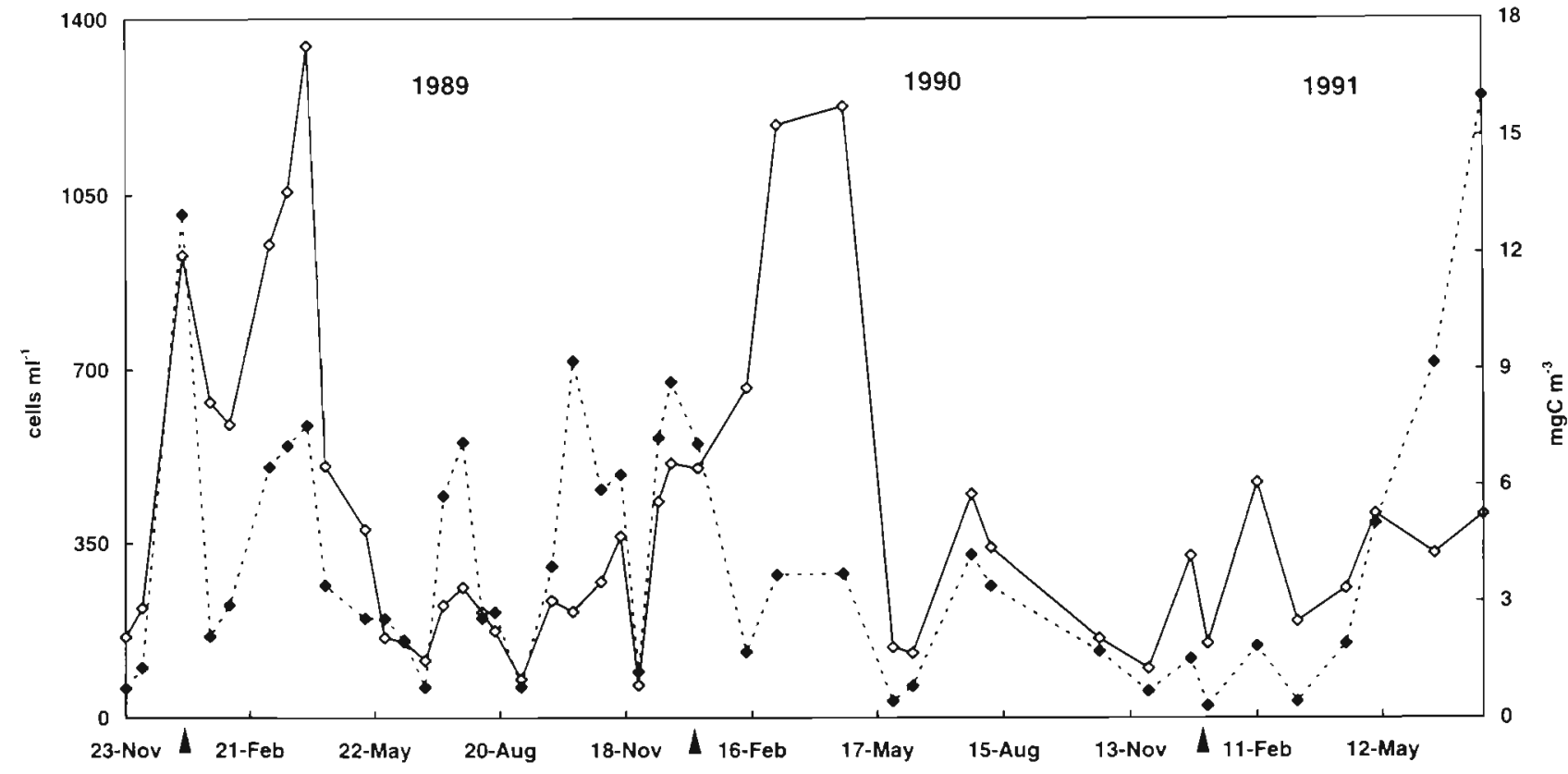

Fig. 5. Seasonal abundance of Lake Kinneret flagellates: $(\bullet)$ average $(0$ to $10 \mathrm{~m})$ cell numbers $\mathrm{ml}^{-1}$, $(\diamond)$ carbon biomass 
high standing stock of HNAN biomass carbon in epilimnic waters during winter and spring was due to large numbers of small flagellates (Figs. $3 \& 5$ ). The profiles in July showed a maximum for HNAN biomass at the thermocline.

\section{Bacterial abundance}

Bacterial numbers ranged from $10^{5}$ to $3 \times 10^{7}$ cells $\mathrm{ml}^{-1}$ over the period from January 1988 to July 1991. The average numbers and fluctuations of bacteria were surprisingly similar in both the upper and the lower water strata (Fig. 6). Generally the highest abundances of bacteria were found towards the end of the dinoflagellate bloom (late April and May) and minimum numbers were observed in June to August 1989 and during winter (January) of 1988 and 1989 (Fig. 6).

In epilimnetic waters, most bacteria were cocci, 0.5 to $1.0 \mu \mathrm{m}$ in diameter (biovolume 0.07 to $0.5 \mu \mathrm{m}^{3}$ ) or small rods about 0.5 to $1.0 \mu \mathrm{m}$ in width and 3 to $5 \mu \mathrm{m}$ in length (biovolume 0.6 to $3.9 \mu^{3}$ ). A few larger cells were occasionally observed.

Bacterial populations from the anaerobic hypolimnion could be easily distinguished from those in the epilimnion. The former were generally larger cells typically filamentous or curved in shape and ranging in size from 1.0 to $2.0 \mu \mathrm{m}$ in width and 2 to $7 \mu \mathrm{m}$ in length (biovolume 5.5 to $6.28 \mu^{3}$ ). During stratification, a significant portion of the hypolimnetic bacterial population consisted of small vibrios or of sulphate reducers such as Desulphovibrio sp. mostly curved or sigmoid in form which are actively involved in sulphate reduction processes (Hadas \& Pinkas 1995).

\section{Interparameter correlations}

We examined our data set for interrelationships between measured parameters (Table 1). Reasonably close correlations were found between the standing

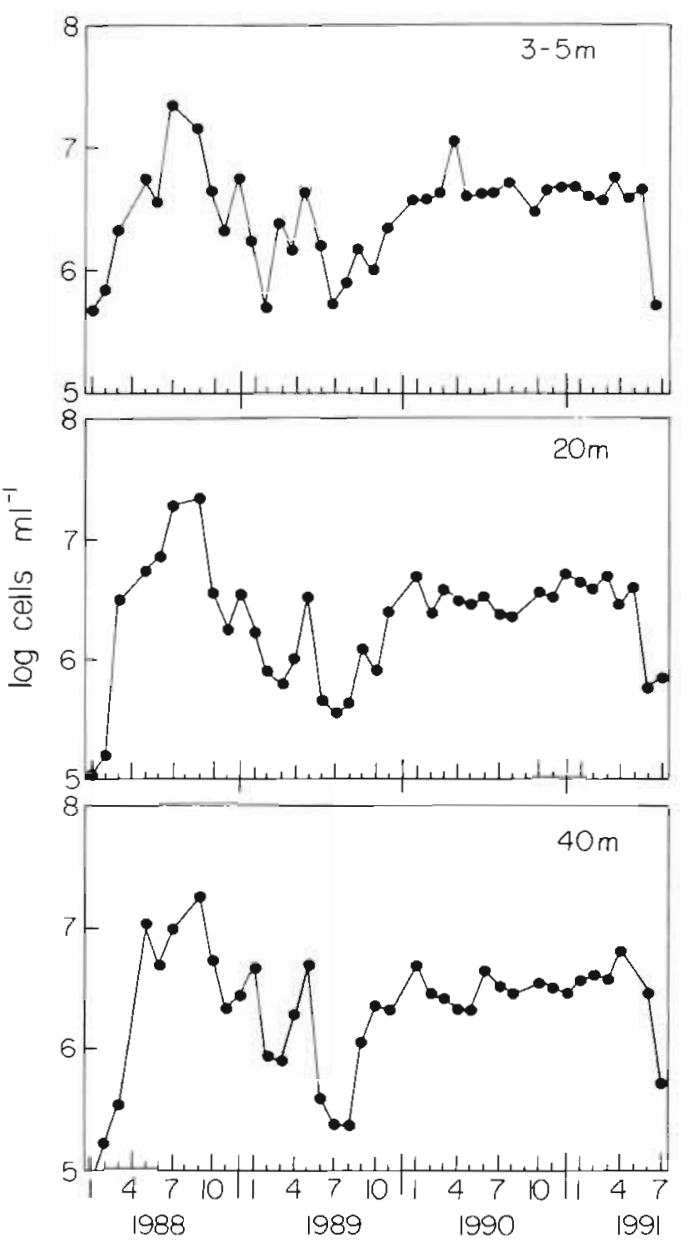

Fig. 6. Bacterial abundance in Lake Kinneret from November 1988 to July 1991 at depths of 3 to 5,20 and $40 \mathrm{~m}$

stocks of flagellate carbon and flagellate cell numbers and also between ciliate carbon and ciliate standing stock numbers. Flagellate numbers were correlated significantly with chlorophyll and with phytoplankton wet weight biomass standing stocks. An inverse relationship was found for the regression of flagellate numbers and picophytoplankton (mostly pico-

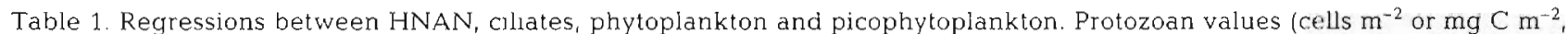
integrated values from 0 to $10 \mathrm{~m}$ ); picophytoplankton (cells $\mathrm{m}^{-2}$ ); phytoplankton biomass ( $\mathrm{g}$ wet weight $\mathrm{m}^{-2}$ ); $\mathrm{chlorophyll}\left(\mu \mathrm{g} \mathrm{l}^{-1}\right.$, average of $15 \mathrm{~m}$ integrated values) and bacterial production (cells $\mathrm{d}^{-1}$, average 0 to $10 \mathrm{~m}$ integrated values measured by ${ }^{3} \mathrm{H}$ thymidine uptake; Berman et al. 1994)

\begin{tabular}{|c|c|c|c|c|c|}
\hline$y$ & ers & $\begin{array}{c}\text { Equation } \\
\qquad y=)\end{array}$ & $\mathrm{n}$ & $r^{2}$ & $\mathrm{p}$ \\
\hline Flagellate carbon & Flagellate cell no. & $1.18 x^{0.78}$ & 40 & 0.41 & $<0.0001$ \\
\hline Ciliate carbon & Ciliate cell no. & $31.56 x^{0.91}$ & 40 & 0.55 & $<0.0001$ \\
\hline Flagellate cell no. & Phytoplankton biomass & $33.7 x^{10.56}$ & 28 & 0.35 & 0.0007 \\
\hline Flagellate cell no. & Chlorophyll & $-178+232.8 \ln (x)$ & 37 & 0.27 & $<0.0001$ \\
\hline Flagellate cell no. & Picophytoplankton cell no. & $1142-161.7 x$ & 27 & 0.23 & 0.009 \\
\hline Flagellate cell no. & Bacterial production & $23.3 x^{0.19}$ & 34 & 0.16 & 0.016 \\
\hline
\end{tabular}


cyanobacteria, see Malinsky-Rushansky et al. 1995). Flagellate or ciliate cell numbers were not significantly correlated to bacterial numbers but flagellate cell numbers were correlated to bacterial productivity albeit with a probability of only $p=0.016$. No other correlates were found for parameters of flagellate or ciliate abundance or carbon biomass

\section{DISCUSSION}

\section{Seasonal patterns of Protozoa in Lake Kinneret}

Our observations in Lake Kinneret indicate a definite seasonal pattern of protozoan distribution which resulted from physical conditions, biological factors and top-down predation pressures.

From February until the beginning of June, Lake Kinneret may be considered eutrophic. Maximum phytoplankton abundance reaches $-250 \mathrm{~g} \mathrm{~m}^{-2}$ (wet weight biomass) or $-300 \mathrm{mg} \mathrm{m}^{-2}$ (chlorophyll) and primary production $-2.5 \mathrm{~g} \mathrm{C} \mathrm{m}^{-2} \mathrm{~d}^{-1}$ (Berman et al. 1995). Most of the dominant Peridinium biomass is not grazed by metazoan zooplankton (Serruya et al. 1980). It has been shown that much of the Peridinium cell material is broken down in the water column (Hertzig et al. 1981), thus implying a 'detrital pathway' of degradation (Serruya et al. 1980) and the presence of a very active microbial loop.

Our observations substantiate this idea. Heterotrophic nanoflagellates dominated the water column from January to June, reaching maximum numbers of $3 \times 10^{3}$ cells $\mathrm{ml}^{-1}$. In January 1988 and 1989, after lake overturn, we observed low bacterial numbers and high HNAN abundance (Figs, $5 \& 6$ ). The decreased bacterial numbers may have been partly due to relatively low $\left(15\right.$ to $\left.16^{\circ} \mathrm{C}\right)$ water temperatures (Cavari \& Hadas 1979) but possibly a more important factor was the grazing pressure of HNAN on bacteria which led to an increase in the former at the expense of the latter.

The role of some ciliate species (including Vorticella, Cyclidium, Coleps sp.) as grazers of picoplankton in a freshwater lake has recently been reported in detail by Simek et al. (1995). We suggest that picophytoplankton may also be a significant food source for ciliates in Lake Kinneret at this season.

In Lake Kinneret in February, peritrich ciliates, mostly Vorticella mayerii, were abundant. These organisms, which filter small particles, are mainly bacterivores (Munawar et al. 1994) and could have been partly responsible for the lowered bacterial and picocyanobacterial numbers in winter. With the onset of the Peridinium bloom in February there was a rise in ciliate abundance, concomitant with the increase of particulate organic detritus (e.g. dinoflagellate theca released with each cell division) and dissolved organic matter which stimulated bacterial (Berman et al. 1979, Cavari \& Hadas 1979) and HNAN outgrowth. As in other freshwater ecosystems, the numbers of HNAN were highest in spring, coinciding with peaks of chl a and primary production (Nagata 1988, Sanders et al. 1989, Munawar et al. 1994).

Low bacterial numbers during winter may be attributed to both decreased water temperatures and the high abundance of flagellates. There were no seasonal fluctuations in bacterial numbers during 1990 perhaps due to the exceptionally mild winter and extremely low rainfall that winter. In winter-spring, the intake requirements (as carbon) of the herbivorous zooplankton have been estimated at $\sim 1.5 \mathrm{~g} \mathrm{C} \mathrm{m}^{-2} \mathrm{~d}^{-1}$ (Serruya et al. 1980). At this time, herbivorous cladocera (Ceriodaphnia reticulata, Diaphanosoma brachyurum, Bosmina longirostris) dominated the zooplankton. Phytoplanktonic primary production during winter-spring in 1989 and 1990 averaged $\sim 2.0 \mathrm{~g} \mathrm{C} \mathrm{m}^{-2} \mathrm{~d}^{-1}$ (Berman et al. 1995) and was due mainly to Peridinium. Since dinoflagellates are not directly grazed by cladocera there appeared to be a shortfall in algal sources to supply the carbon demand of the herbivorous zooplankton (Serruya et al. 1980). Stone et al. (1993) have suggested that some of this requirement may be supplied by protozoa, with ciliates providing almost half of the food needs of the copepods.

In laboratory experiments, cladocerans and young cyclopoid copepods isolated from Lake Kinneret were shown to feed upon the ciliates Stylonichia, Cyclidium and Colpoda (Berman \& Gophen pers. comm.). These food sources enabled growth and reproduction of the metazoan zooplankton although at lower rates than when nanoplanktonic algae were grazed.

A short transition period from about mid-May through June prior to the onset of typical summerautumn conditions is characterized by intense bacterial activity. Cavari \& Hadas (1979) observed the highest bacterial numbers and a $78 \%$ increase in bacterial glucose assimilation rates at the beginning of summer after the decline of the Peridinium bloom. In addition, the increase of epilimnetic water temperatures from -20 to $26^{\circ} \mathrm{C}$ and the onset of strong thermal and chemical stratification creates a layer rich in food sources for bacteria. At this time high numbers of ciliates and flagellates were found in the metalimnic layer (Fig. 3; May) as has been reported elsewhere (Berninger et al. 1991).

Similarly to observations in many other water bodies (Fenchel et al. 1990, Cole et al. 1993), bacterial cells in the anaerobic hypolimnion of Lake Kinneret were generally larger than those in the upper water layers (Schmaljohann et al. 1987). The smaller size of bacteria in epilimnetic waters might be due to the pressure of 
protozoa and cladocerans, which appear to feed selectively on larger cells (Gonzalez et al. 1990), and/or to the different taxonomic composition, since anaerobic (hypolimnetic) taxa generally have much larger cell size.

During the summer and autumn (from July through December), Lake Kinneret is mesotrophic with chlorophyll concentrations of 5 to $8 \mu \mathrm{g} \mathrm{l}^{-1}$ and primary production of $\sim 1.2$ to $1.6 \mathrm{~g} \mathrm{C} \mathrm{m}^{-2} \mathrm{~d}^{-1}$. Despite a switch in phytoplankton to a population dominated by small chlorophyta that maintain high levels of primary production, the herbivorous zooplankton may still require supplemental food sources, especially in view of their increased respiratory rates. On the basis of model simulations, Stone et al. (1993) suggested that, at this season too, ciliates are an important food source for the copepods while bacteria might provide about $10 \%$ of cladoceran requirements. Note that the protist carbon biomass ( 780 to $1160 \mathrm{mg} \mathrm{C} \mathrm{m}^{-2}$ ) in autumn was somewhat greater than that of the metazooplankton, $620 \mathrm{mg}$ $\mathrm{C} \mathrm{m}^{-2}$ (Sherr et al. 1991).

From August to December, copepods were usually the dominant metazooplankton. Although adult copepods are strict predators (Gophen 1978) and may have imposed strong pressure on ciliates, HNAN and cladocera at this season (Stone et al. 1993), nevertheless high numbers and biomass of ciliates were observed in autumn. Cyclidium sp. was abundant in the epilimnion while in the hypolimnion, Coleps hirtus, a macropredator able to feed on a large variety of food sources (Madoni et al. 1990), was dominant. In turn, predation by ciliates may have limited the HNAN population which dropped to 66 cells $\mathrm{ml}^{-1}$.

\section{Sediment-water interface}

The ciliate community had the greatest numbers of individuals at the sediment-water interface. Here the ciliate species were characteristic of a sulfuretum. The large numbers of ciliates observed in the metalimnic layer may have been feeding on colorless sulfur bacteria which are numerous and show high chemosynthetic activity at the aerobic/anaerobic interface (Hadas unpubl. data). A similar phenomenon was found in the Black Sea (Zubkov et al. 1992) where the protist community was reported to be a major factor in the utilization of chemotrophic bacterial production.

\section{Patterns of protozoan abundance}

A priori we expected to find some relationship between the abundance of bacteria and that of the bacterivorous protozoa, especially HNAN. However, considering the lengthy intervals between sampling times ( 2 or $4 \mathrm{wk}$ ) and the rapid growth rates reported for HNAN in this lake $\left(0.03\right.$ to $0.11 \mathrm{~h}^{-1}$; Hadas et al. 1990), the absence of any evident relationship between HNAN standing stocks and bacteria is perhaps not surprising. Moreover, it seems reasonable that a direct relationship should exist between HNAN (cell numbers) and bacterial productivity (see Table 1), especially if the majority of bacteria cropped by the HNAN tend to be larger, actively dividing cells (Gonzalez et al. 1990). Clearly, in order to study the dynamics of HNAN and bacterial populations in the natural environment, more frequent ( 12 hourly) sampling would be required

In Lake Kinneret, cell numbers of both HNAN (Fig. 5) and ciliates (Fig. 2) showed regular oscillating patterns which were less evident in the biomass data. These oscillations had a periodicity of 2 to $3 \mathrm{mo}$, much longer than the cyclical patterns usually found for protozoan predator-prey relationships, which are generally in the order of 1 or $2 \mathrm{wk}$. This cyclical phenomenon was most pronounced throughout 1989 and less so in 1990. It would seem unlikely that the patterns observed in Figs. 2 \& 5 were due to some sampling or counting artifact but at present we have no clear explanation for these observations. Elsewhere HNAN numbers have also shown considerable fluctuations (Nagata 1988, Bennett et al. 1990, Laybourn-Parry \& Rogerson 1993). These fluctuations suggest that HNAN do not increase as much as they could because some other consumers (ciliates, zooplankton) can quickly respond to any increase in HNAN (Gasol \& Vaqué 1993). Such long-term cyclical behaviour for natural protozoan populations may reflect shifts in the structure of the microbial loop which act to maintain an overall system stability in the face of environmental perturbations.

Our observations suggest that significant amounts of bacterial production may be transferred to higher levels of the plankton via HNAN and ciliates in Lake Kinneret. Protozoan grazing appears to be a major determinant of both bacteria and picocyanobacterial abundance in this lake as in other aquatic environments (Scavia \& Laird 1987, Weisse 1990, Berninger et al. 1991, Sanders et al. 1992, Kuuppo-Leinikki et al. 1994). Predation by metazooplankton on components of the microbial food web, especially on ciliates, may be responsible for an important transfer of carbon to higher trophic levels in this lake.

Acknowledgements. We thank Gili Nahum, Hela Yehuda, Sara Chava for technical assistance. This study was supported by Grant No. 87-206 from the United States-Israel Binational Science Foundation (BSF), Jerusalem, Israel. 


\section{LITERATURE CITED}

APHA (1989) Methods for examination of water and wastewater, 17 th edn. American Public Health Association, Washington, DC

Azam F, Fenchel T, Field JG, Meyer-Reil LA, Thingstad T (1983) The ecological role of water-column microbes in the sea. Mar Ecol Prog Ser 10:257-263

Beaver JR, Crisman TL (1989) The role of ciliated protozoa in pelagic freshwater ecosystems. Microb Ecol 17:111-136

Bennett SJ, Sanders RW, Porter KG (1990) Heterotrophic, autotrophic and mixotrophic nanoflagellates: seasonal abundances and bacterivory in a eutrophic lake. Limnol Oceanogr 35:1821-1832

Berman T, Hadas O, Marchaim U (1979) Heterotrophic glucose uptake and respiration in Lake Kinneret. Hydrobiologia 62:275-282

Berman T, Hoppe HG, Gocke K (1994) Response of aquatic bacterial populations to substrate enrichment. Mar Ecol Prog Ser 104:173-184

Berman T, Stone L, Yacobi YZ, Kaplan B, Schlichter M, Nishri A, Pollingher U (1995) Primary production and phytoplankton in Lake Kinneret: a long-term record (19721993). Limnol Oceanogr 40:1064-1076

Berninger UG, Finlay BG, Kuuppo-Leinikki P (1991) Protozoan control of bacterial abundances in freshwater Limnol Oceanogr 36:139-147

Bick H (1972) Ciliated Protozoa. World Health Organization, Geneva

Bird DF, Kalff J (1984) Empirical relationships between bacterial abundance and chlorophyll concentrations in fresh and marine waters. Can J Fish Aquat Sci 41:1015-1023

Bloem J, Bar-Gilissen MJB (1989) Bacterial activity and protozoan grazing potential in a stratified lake. Limnol Oceanogr $34: 297-309$

Børsheim KY, Bratbak G (1987) Cell volume to cell carbon conversion factors for a bacterivorous Monas sp. enriched from sea water. Mar Ecol Prog Ser 36:171-175

Cavari BZ, Hadas O (1979) Heterotrophic activity glucose uptake and primary productivity in Lake Kinneret. Freshwater Biol 9:329-338

Cole JJ, Pace ML, Caraco NF, Steinhart G (1993) Bacterial biomass and cell size distribution in lakes: more and larger cells in anoxic waters. Limnol Oceanogr 38:1627-1632

Dolan JR, Gallegos C (1991) Trophic coupling of rotifers, microflagellates and bacteria during fall months in Rhode River. Mar Ecol Prog Ser 77:147-156

Fenchel T, Kristensen LD, Rasmussen L (1990) Water column anoxia: vertical zonation of planktonic protozoa. Mar Ecol Prog Ser 62:1-10

Gasol JM, Vaque D (1993) Lack of coupling between heterotrophic nanoflagellates and bacteria: a general phenomenon across aquatic systems? Limnol Oceanogr 38:657-665

Gonzalez JM, Sherr EB, Sherr BF (1990) Size selective grazing on bacteria by natural assemblages of estuarine flagellates and ciliates. Appl Environ Microbiol 56:583-589

Gophen M (1978) Zooplankton in Lake Kinneret. In: Serruya C (ed) Monographiae Biologicae. Dr W Junk Publishers, The Hague, p 297-311

Gophen M, Cavari BZ, Berman T (1974) Zooplankton feeding on differentially labelled algae and bacteria. Nature 247 : 393-394

Hadas O, Pinkas R (1995) Sulphate reduction in the hypolimnion and sediments of Lake Kinneret, Israel. Freshwater Biol 33:63-72

Hadas O, Pinkas R, Albert-Diez C, Bloem J, Cappenberg T, Berman T (1990) The effect of detrital addition on the development of nanoflagellates and bacteria in Lake Kinneret. J Plankton Res 12:185-199

Hertzig R, Dubinsky Z, Berman T (1981) Breakdown of Peridinium biomass in Lake Kinneret. In: Shuval H (ed) Developments in and zone ecology and environmental quality. Balaban ISS, Philadelphia, PA, p 179-185

Kuuppo-Leinikki P, Autio R, Hallfors S, Kuosa H, Kuparnen J, Pajuniemi R (1994) Trophic interactions and carbon flow between picoplankton and protozoa in pelagic enclosures manipulated with nutrients and a top predator. Mar Ecol Prog Ser 107:89-102

Laybourn-Parry J, Rogerson A (1993) Seasonal pattern of protozooplankton in Lake Windermere, England. Arch Hydrobiol 129:25-43

Madoni P (1990) The ciliated protozoa of the monomictic Lake Kinneret (Israel): species composition and distribution during stratification. Hydrobiologia 190:111-120

Madoni P, Berman T, Hadas O, Pinkas R (1990) Food selection and growth of the planktonic ciliate Coleps hirtus isolated from a monomictic subtropical lake. J Plankton Res 12 : 735-741

Malinsky-Rushansky N, Berman T, Dubinsky Z (1995) Seasonal dynamics of picophytoplankton in Lake Kinneret, Israel. Freshwater Biol 34:241-254

Munawar M, Munawar IF, Weisse T, Leppard GG, Legner M (1994) The significance and future potential of using microbes for assessing ecosystem health: the Great Lakes example. J Aquat Ecosyst Health 3:295-310

Nagata T (1988) The microflagellate-picoplankton food linkage in the water column of Lake Biwa. Limnol Oceanogr 33:504-517

Pace ML, McManus GB, Findlay SEG (1990) Planktonic community structure determines the fate of bacterial production in temperate lake. Limnol Oceanogr 35:795-808

Pollingher U, Kimor B (1967) The tintinnid fauna of Lake Tiberias. Sea Fish Res Stn Haifa Bull 44:17-21

Pomeroy LR (1974) The ocean's food web, a changing paradigm. BioSci 9:499-504

Porter KG, Feig YS (1980) The use of DA.PI for identifying and counting aquatic microflora. Limnol Oceanogr 25:943-948

Porter KG, Pace ML, Battey JF (1979) Ciliate protozoans as links in freshwater planktonic food chains. Nature 277 : 563-565

Putt M, Stoecker DK (1989) An experimentally determined carbon:volume ratio for 'oligotrichous' ciliates from estuarine and coastal waters. Limnol Oceanogr 34:1097-1103

Sanders RW, Caron DA, Berninger UG (1992) Relationships between bacteria and heterotrophic nanoplankton in marine freshwaters; an interecosystem comparison. Mar Ecol Prog Ser 86:1-14

Sanders RW, Porter KG (1990) Bacterivorous flagellates as food resources for the freshwater crustacean zooplankter Daphnia ambigua. Limnol Oceanogr 35:188-192

Sanders RW, Porter KG, Bennett SJ, DeBiase AE (1989) Seasonal patterns of bacterivory by flagellates, ciliates, rotifers and cladocerans in a freshwater planktonic community. Limnol Oceanogr 34:673-687

Scavia D, Laird GA (1987) Bacterioplankton in Lake Michigan: dynamics, controls, and significance to carbon flux. Limnol Oceanogr 32:1017-1033

Schmaljohann R, Pollingher U, Berman T (1987) Natural populations of bacteria in Lake Kinneret. Observations with scanning electron and epifluorescence microscopy. Microb Ecol 13:1-12

Serruya C, Gophen M, Pollingher U (1980) Lake Kinneret: carbon flow patterns and ecosystems management. Arch Hydrobiol 88:265-302 
Sherr BF, Sherr EB, Berman $T$ (1982) Decomposition of organic detritus: a selective role for microflagellate protozoa. Limnol Oceanogr 27:765-769

Sherr EB, Sherr BF, Berman T, Hadas O (1991) High abundance of picoplankton-ingesting ciliates during late fall in Lake Kinneret 1991. J Plankton Res 13:789-799

Sherr EB, Sherr BF, Paffenhöfer GA (1986) Phagotrophic protozoa as food for metazoans: a missing trophic link in marine pelagic food webs? Mar Microb Food Webs 1: $61-80$

Simek K, Bobkova O, Macek M, Nedoma J (1995) Ciliate grazing on picoplankton in a eutrophic reservoir during the summer phytoplankton maximum: a study at the species and community level. Limnol Oceanogr 40:1077-1090 Stoecker DK, Capuzzo JM (1990) Predation on protozoa: its

Editorial responsibility: Fereidoun Rassoulzadegan, Villefranche-sur-Mer, France importance to zooplankton. J Plankton Res 12:891-908

Stone L, Berman T, Bonner R, Barry S, Weeks SW (1993) Lake Kinneret: a seasonal model for carbon flux through the planktonic biota. Limnol Oceanogr 38:1680-1695

Weisse T (1990) Trophic interactions among heterotrophic microplankton, nanoplankton and bacteria in Lake Constance. Hydrobiologia 191:111-122

Weisse T, Muller H (1990) Significance of heterotrophic nanoflagellates and ciliates in large lakes: evidence from Lake Constance. In: Tilzer MM, Serruya C (eds) Dynamic processes in large lakes. Science Techn Publ, SpringerVerlag, Berlin, p 540-555

Zubkov MV, Sazhin AF, Flint MV (1992) The microplankton organisms at the oxic-anoxic interface in the pelagical of the Black Sea. FEMS Microbiol Ecol 101:245-250

Submitted: May 31, 1996; Accepted: May 9, 1997

Proofs received from author(s): November 17,1997 